\title{
MALIGNANT MELANOMA OF THE NOSE AND PARANASAL SINUS
}

\author{
HISAKI SAITO, M.D., JIRO HOZAWA, M.D., MASARU HAKAMADA M.D., \\ AND MASAAKI KASAHARA, M.D. \\ Department of Otorhinolaryngology, Hirosaki University, School of Medicine
}

(Director: J. Ho:azea, M.D.)

\begin{abstract}
Six patients with malignant melanoma in nasal cavity and paranasal sinus were treated in our clinic during 27 years from 1950 to 1976. Age ranged from 49 to 79 years. Sex distribution was 3 males and 3 females. The malignant melanoma was observed in nasal septum in three cases. In remaining three cases it developed in middle turbinate, in middle meatus, and in middle turbinate as well as maxillary sinus, respectively. They were treated with a combination of operation, irradiation, and administration of anticancerous drugs. In two cases, who were treated recently, immunotherapies (BCG etc.) were also administered.

One case, whose tumor was classified as the spindle cell type histologically, survived more than five years without recurrence. Four of the five cases with the large epitheloid cell type died within one and a half year. Remaining one case, treated with BCG and ${ }^{60} \mathrm{Co}$ irradiation has been surviving for about ten months.

Electron micrograph of one case revealed large nuclei and deep invaginations of the nuclear membranes, but no desmosome in cell membranes. The nuclei contained very large nucleoli and exhibit some vacuolelike structures.

Autopsy was performed in two cases. One case showed predominant, bone metastasis (the cranial base and the spinal column ctc.) along with lung metastasis. In the second case, predominant visceral metastasis (lungs, liver, and pancreas etc.) was observed as well as pleura, bone (the spinal colum etc.) and forehead skin metastasis.

We collected $6 z$ cases of malignant melanoma in nose and paranasal sinus from Japanese literature (which were published from 1965 to 1975). In Japan, malignant melanomas originated in nasal cavity and paranasal sinus are thought not so rare disease as mentioned before.
\end{abstract}

\section{A $80-1338-30339$}

\section{[粟田口省吾教授退官記念論文］ \\ 鼻 副鼻腔覀性黑色腫の6 例}

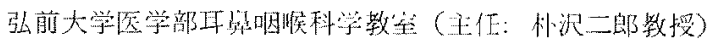

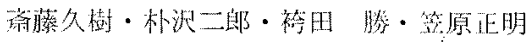

\section{I. 緒晋}

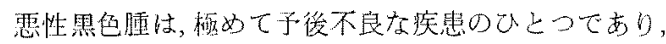

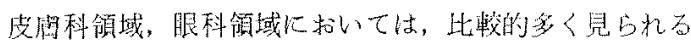

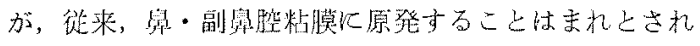

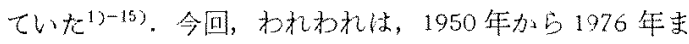

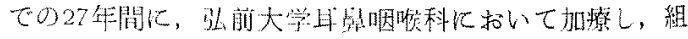

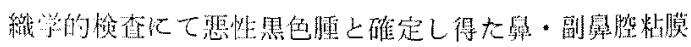

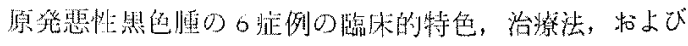

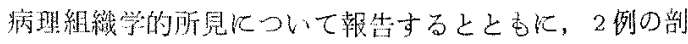

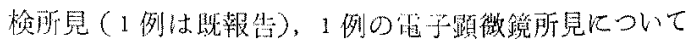


報告し, 若干の文献的検討を加えた.

II. 症例

症例 1, 49歳, 男子, 農業.

初診: 1950年 4 月 3 日.

主訴: 右側䫇下部腫脹, 右側鼻腔内腫痹.

既往歴：特記すべきことはない。

現病歷：1948年10月頃，右側顎下部に大豆大の腫瘤を 認め，次第に增大す 同じ頃より，右側鼻腔に腫瘤が発 生し，鼻出血扣よび，鼻閉を認旮。某耳鼻科医にて，慢 性副鼻煠炎, 鼻茸の診断のもとに，1949年6月鼻茸切除 術を受けた。同年8月と10月にも，再発のために鼻藏切 除術を受けている.同年11月頃より, 右側顎下部の腫脹 が急激化增大した。1950年 4 月 3 日当科受㟝し， 4 月 26 日に入院した.

入院時所見㧍よび経過：右側固有鼻腔は暗赤色の腈瘍 で充満し, 鼻翼部の腫脹を認む。右側顎下部に鶏卵大の 腫瘤を触知す４月２6日，Kretschmann 法による舀中 隔手術を行ない, 右側州入口部から, 鼻中隔右側前部, 右側下鼻甲介にかけての腫瘍を切除した。同時に, 右側 上勁洞のCaldwell-Lnc 手術を施行したが，上顎洞内に は腫瘍の侵襲を認めなかった。 5 月 26 日に退院した。退 院時に, 身翰前部に 8 個, 身翰後部に 9 倜, 右側䓵下部 飞1 個の米粒大ないし琶卵大の皮筒転移巣を認む. 1950 年7月 27 日, 永眠した.

病理組織学的所見: 主として, 大型類円形ないし多角 形を示す比較的明るい腫瘍細胞の充実性增殖を認めた. 胞体内儿褐色の色素を有する細胞が散在していた。 证例 2, 59藏, 女子, 無職.

睤中隔左側粘膜から発生した症例で，1957年に教室の 原田 ${ }^{2)}$ が報告しているので, 参照されたい。試験切除片 の病理組織学的所見では, 黒色色素を有する媑瑒細胞を 認めたが, 総て成熟したもので悪性の像とは思われない という返事であった. 入院後. 1 年 3 力月目に永眠した. その間, 最初の手術を受けた㣪, 一時退院し, 再入院後 2 回にわたって手術を受けた. 剖検の結果, 頭蓋肖は, 前頭洞扰よび箱板にそれぞれ径 $5 \mathrm{~cm}$ 大の骨欠損を言热め, 頭蓋底も破壊され，腫瘍は大脳前頭葉まで侵入してい

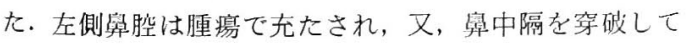
右側䁷腔にも及んでいた，身体他部一の転移は，骨転移

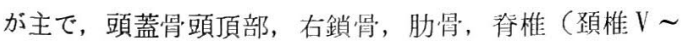
III, 胸椎 $V I \sim \mathbb{X})$ ，腸骨等に転移が見られた。他に肺転 移を認めた。剖検標本の病理組織学的所見では, 大型 淡明の腫瘍細胞が, 胞栄状に增殖し, 間質は少なく, 煄
煌細胞の大多数は, 胞休内に微細顆粒状の色素を有して Wた.

症例 3, 67歳, 男于, 姐棠

䘞䧐：1963年5月 8 日.

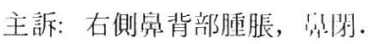

既仆:榃：特記すべきことはない，

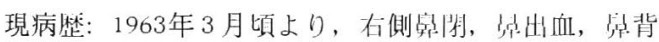

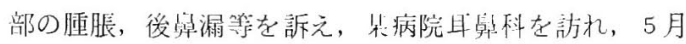
8 日, 当科に紹介され, 即日入院した.

入院時所見：全身所見は特に異常なく，䅡部リンパ節

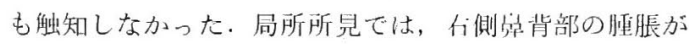
あり, 定入口蔀には, 易出血性の黑色の腫場が充満して いた。㟔X線写真では, 両侧上顎洞に怪度の㓌影增強を 認めたが，骨诐壞は認めなかった。

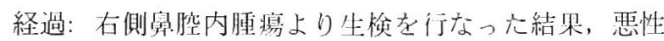
黑色梗の診断を得たので，5月20日に，Caldwell-Luc 法 に準じて手術を施し，同時に，菛中隔の部分切除を行な った。上顎洞粘朕は線維性に肥厚し，洞内には峎汁を就 めたが，上顎洞内や中鼻道には腫陽の侵熋を吠めなかっ

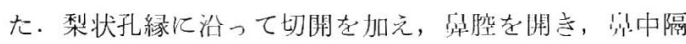

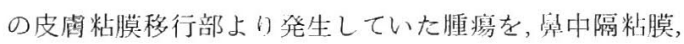
㳄骨膜, 㳄胃の前 $1 / 3$ と共に切除し, 創縁は, 它気凝固 を行なった。術後，6月1日から6月 24 日まで ${ }^{60} \mathrm{Co}$ 照 射 1 日量 $250 \mathrm{rads}$ t 20 回, 計 $5,000 \mathrm{rads}$ 施行し，6月 28日に退院した。 その後再発を認め才゙，1969年3月4日 に，他疾患で永肺した。

病理組織学的所見：主として紡鍕形の腫揚細胞が，密 に，あるいは踈に配列して增殖し，多くの腫瘍細枹は胞 体内に蝎色色素を有していた（図1).

症例 4, 62蒇, 男」，会社員.

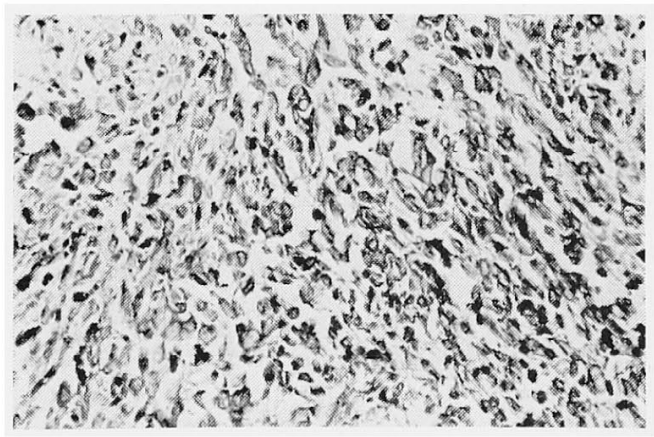

図 1 病理組織像: 紡鍾形の腫揚細胞が, 涋に, あ るいは疎に配列して增殖している。

(H.E. 氿色, 100 倍撮影) 
初豄：1970年12月1日.

主訴：右侧察出血.

既往楸：35歳の㭙に朋炎に程患。

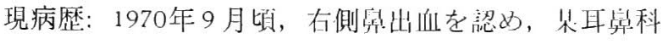

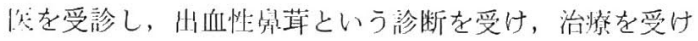

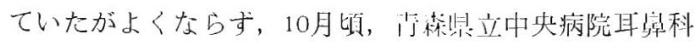
を訪れ，右侧舅腔内腫瘤を生検の結果，単純性血管腫の

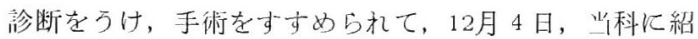

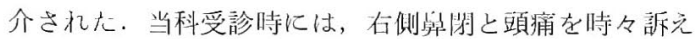
ていた。

入院時所見：全身所見は特に異常なく，頝部リンパ節

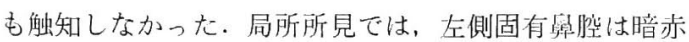
色の鼻茸様腫瘤が充満していた，左後贸控にも同様の腫 瘤が充満していた。鼻部X線写真では, 上顎洞, 飾骨洞 に陰影増強を認め，鼻腔側壁に骨破壊を認めた。

経過：1970年12月16日，Denker 氏法に準じて手術を 施行した. 左側上顎洞粘膜は肥厚して, 一部に黒点を䛱

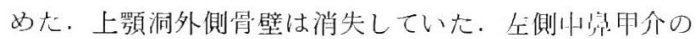

ほとんどと下留甲介の前の方の一部分は，悬茸様の黒い 組織に置き換わっていた，舁中隔粘膜の前の一部分にも

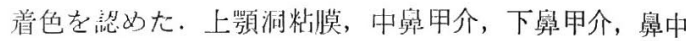
隔粘膜の着色部分は, 健常部分を含めて可及的に切除し た. 術後, ブレオマイシン 1 日量 $15 \mathrm{mg}$ を週 3 回, 計 $150 \mathrm{mg}$ 投! jし，1971 年1月28日に退院した. その後, 敦森県立中央病院耳舅科にて経過観祭していたが，再発 転移し，1972年6月15日に永䀝した。

病盟組織学的所見：粘膜下に，類円形ないし多解形の 大型の腫湟組胞の髄様增殖を認めた。胞体内にはメラニ ンを含有し, mitosis も非常に多く,出血が高度であった。 症例 5,51 墄, 女子, 農業.

初診: 1976年4月16日.

主訴: 左側鼠出血, 鼻閉.

既往歷：4歳の時, Polio 飞瞿患し, 右下肢に軽度の 趾行あり.40歳の時, 胃潰瘍に罹患した.

現病暦：1975年秋頃より左側鼻閉と少量の㗜出血を認 めた。同年12月10日, 某耳鼎科医を受診し, 出血性鼻茸

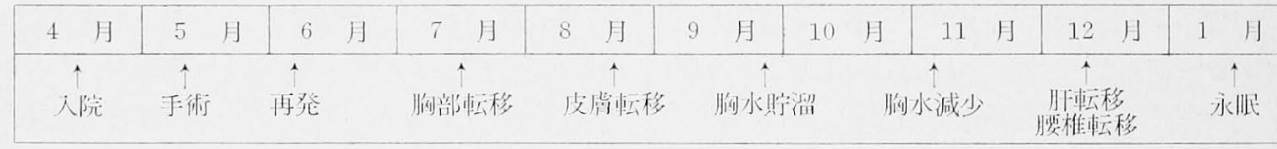
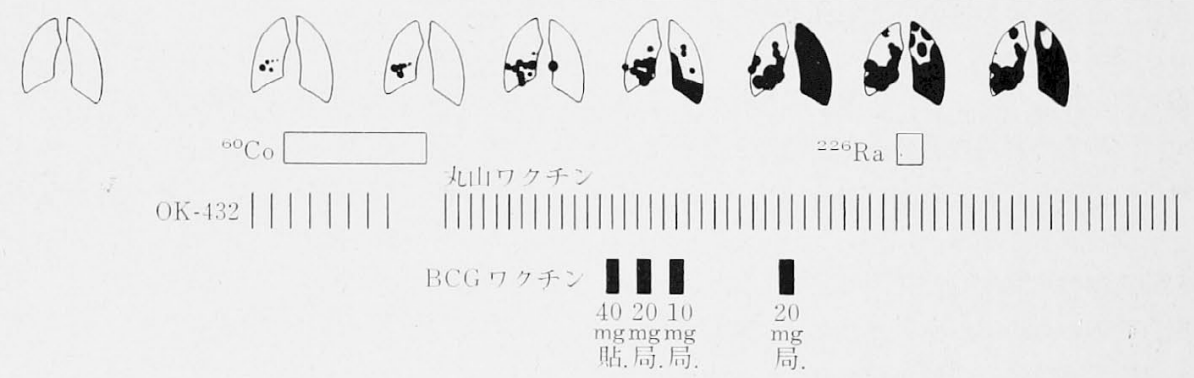

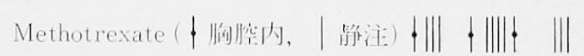

$\|$

プトニソロン内服

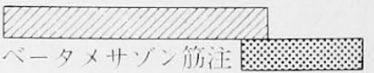

PPD ( \pm

(H) (H) (H)

$(-)$

(+) (-)

DNCB $(+)$

$(-)$

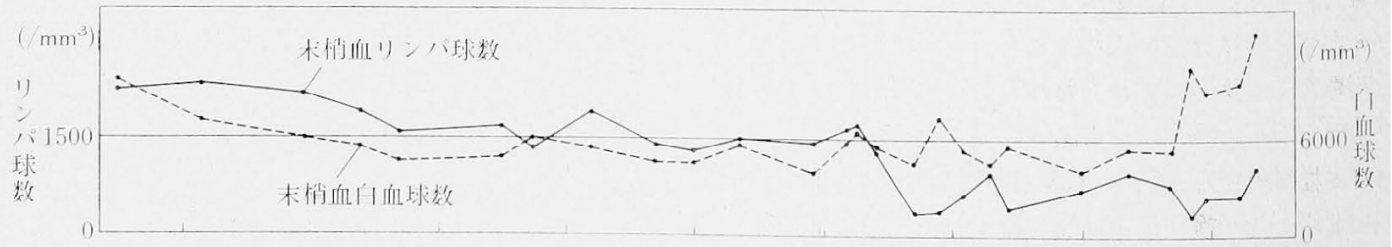

図 2 症例 5 の 経 過 
の診断にて, 算咠切除術を受けた. 1976年 3 月初旬, 再 び左側鼻閉が出現し, 案出血も時々認め, 鼻茸切除術之 上顎洞根本手術を锥められていたが，4月14日と15日に 多量の質出血を認めたため，4月16日，当科に紹介され， 救急車にて即日入院した.

入院時所見：全身所見では，右下肢に怪い片麻痻を訫 める以外に異常なく，頝部リンパ節も触知しなかった。 局所所見では，左側固有鼻腔は易出血性の暗赤色の腫将 で充満していた、鼻部X線写真では, 左側上顎洞, 箱贯 洞に陰影増強を認め, 左側固有舅腔内に腫陽陰影を認め, 左鼻腔側壁の一部に骨破壊を認めた。

経過 (図 2)：4月17日に, 左側固有鼻腔内の生㭘を施 行した. 組織学的診断は, 炎症性肉芽組織であったが, 悪性細網症等も否定できないとの事であった４月 月 30 日 の, 2 回目の生検の結果も同様の診断であった. 確定診 断のつかないまま, 5 月10日に, Caldwell-Luc 法によっ て手術を施行した. 左側上顎洞粘膜は線維性に肥厚し, 洞内には膿汁を認めたが悪性像はなかった。中鼻甲介前 端に小指頭大の黑い腫瘍を恋め, それより後部にも同様 の腫瘍が充満しており，腫場の大部分は中鼻甲介ととも に後鼻孔加ら上咽頭を通って摘出した. 中鼻甲介の前半

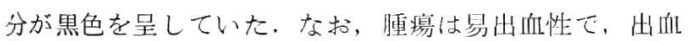
量は約 $800 \mathrm{ml}$ であった. 切除愫本の組織学的診断は, 悪性黒色腫であった。術㣪1 力月目に局所再発を認め た. 6 月12日上り, OK-432の点滴静注 (週 2 回潮増), 6月 26 日より， “”C 0 遠隔照射を開始したが，効果はは とんど認められす OK-432 は, 発繁, 胸部痛等の副作 用が強く中止した。7月 15 日，両側胸部転移を就卆？ 月26日より，丸山ワクチン（A淡，B液隔日皮下注）存 使用した。 8 月 20 日頃より, 前頭部存側に黑色の皮虞転 移が出現した。9月中旬に, 左側胸膜腔に胸水賭溜を認 む.9月6日より, BCG ワクチンの局注を 4 回にわた つて施行した. 最初 $40 \mathrm{mg}$ を界腔内腄瘦に局所貼布し, 副作用がなかったので，7 日後に20 mg を局注した. 続 いて，10日後に $10 \mathrm{mg}$ を前頭部の皮㲊転移栄に局注し たところ, 約 80 分俊激しい悪感戦懆と $38^{\circ} \mathrm{C}$ 台の発熱 在訴えた。 $25 \%$ スルピリンの注射により解熟したが，そ の後 3 日間, 発熱を認めた. 胸水眝溜が增大してきたの で, 9月30日から10月20日まで, 計 4 回にわたって、1 回量約 $1,000 \mathrm{~m} l$ 前後の血性胸水を左側胸腔内力ら第刺 排液した. その際, methotrexate を $20 \mathrm{mg}$ ずつ胸腔内 に汸入した，胸水の細胞診では，異型細胞は認めなかっ た.10月末からは, methotrexate の静注とプレドニン
ロンの内服とを併用し，胸水の貯溜傾向が少なくなっ

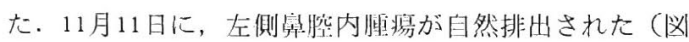
3). 残った脘内腫瘍には Ra 針による組織内照射を行 なった，同時に，クロルプロマジン内服 (1 日星 $100 \mathrm{mg}$ ) を僧用した，12月中的，腰椎怯移を認卆．細胞免疫能の 指標として，PPD皮内反心，DNCB反応(川㥓 ${ }^{58}$ )の方法 扣よび判定を準用)，末梢血りンパ球数を測定したＰPD 皮内反応は，丸山口クチン投与後陽転し，抗癌郕投与後 陰性化した。闹時に, DNCB 反応も陰性化した，末梢血 リンパ球数は, 抗癌剂投与後著明に減少した. その後, 呼吸困難が増大し，1977年1月16日に永眠した。永眠の 前日まで意識は明睹であった。

病理組織学的所見：大型類円形の腫瘍細胞が胞巣性に 増殖していた，胞体内に茶裼色細顆粒状色素を認める細 胞を一部に認めた。色榇は鉄反応陰性で, 腫瘍細胞は Dopa 反応陽性を示した. 図 4 は組織化学所見 (Dopa 反 灾）で, Dopa 陽性細胞が腫瘍組織内に散在している. な拉，Dopa 陽性細胞は，粘膜基底層付近に多く見られ る.

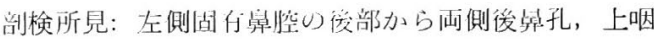
頭にかけて黑色腫瘍が充満し，两側胸膜には，図 5 のご とく著明な転移巣を認め, 胸朕腔は約半分位に狭められ ていた。また，両側肺実質のほとんどが腫瘍化していた。 肝臟の死䈎の一部が破れて，腹腔内には，黒色泥状物質

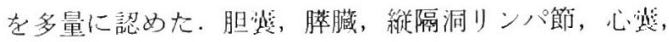

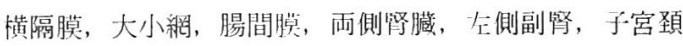

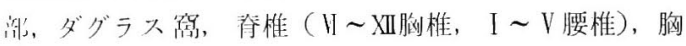

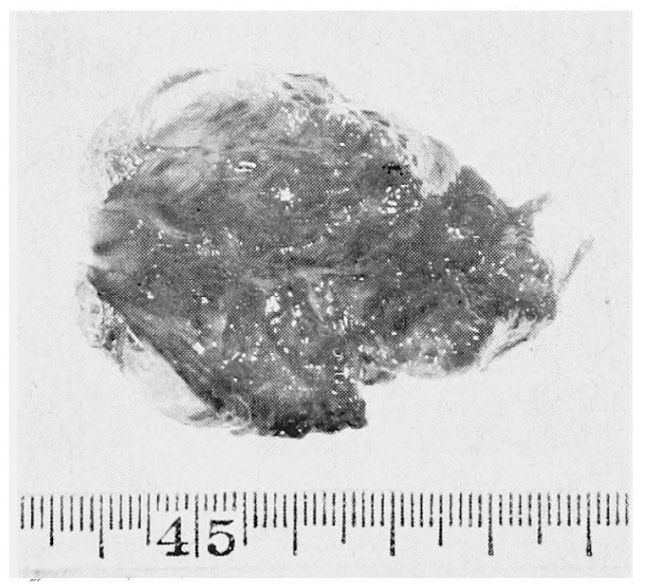

図 3 自然排出された禀腔内腫瘍の割面. 黒色に着 色した部分と, 着色のない amelanotic の部分 とが混在していた。 
肖, 肋骨飞枟移を認め大。皮简枟移は左前頭部の1個の みであった。家族の希坒により頭蓋腔は開かなかった。

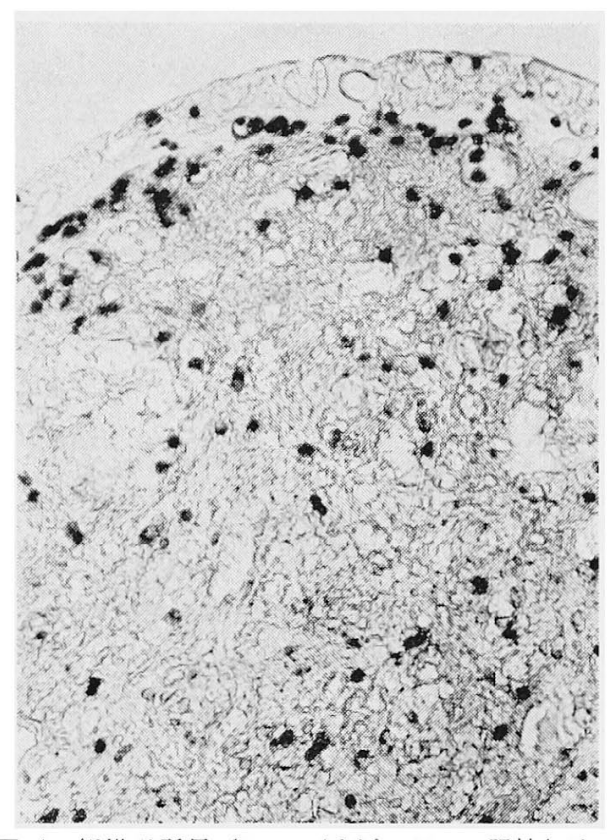

図 4 組織学所見 (Dopa 反応): Dopa 陽性細胞が 腫瑒組織内に敞在している。(100倍撮影)
症例 6, 79 藏, 女小”, 無職.

初診: 1976年 8 月16日.

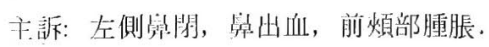

既往歴：1974年12月枕から当科受診時まで，高血圧と

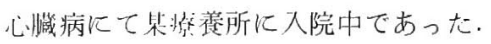

現病歴: 1976年7月10日頃, 左側鼻出血, 秿閉, 鼻内

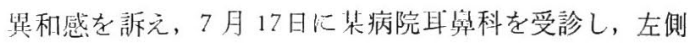
固有鼻腔に㣫瘤症認めたため, 生検を 2 回施行したが, 2 回上屯買死が主体で一部に肉腫を思わせる腫癔細胞を 認めたのみであった。碓定診断がつかないまま, 舅腔内

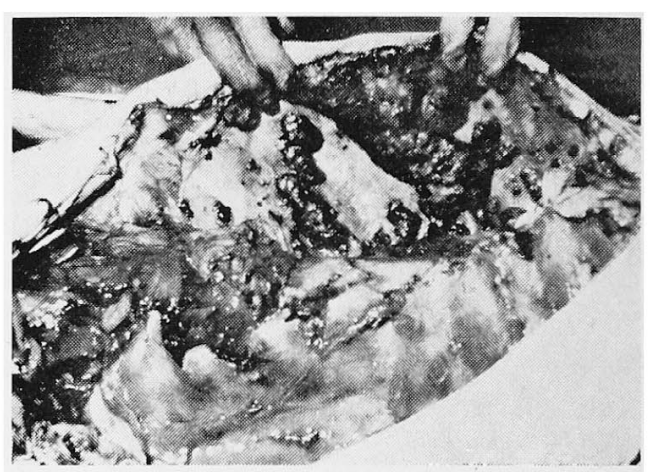

図 5 剖検所見：著明な胸膜転移を認めた。

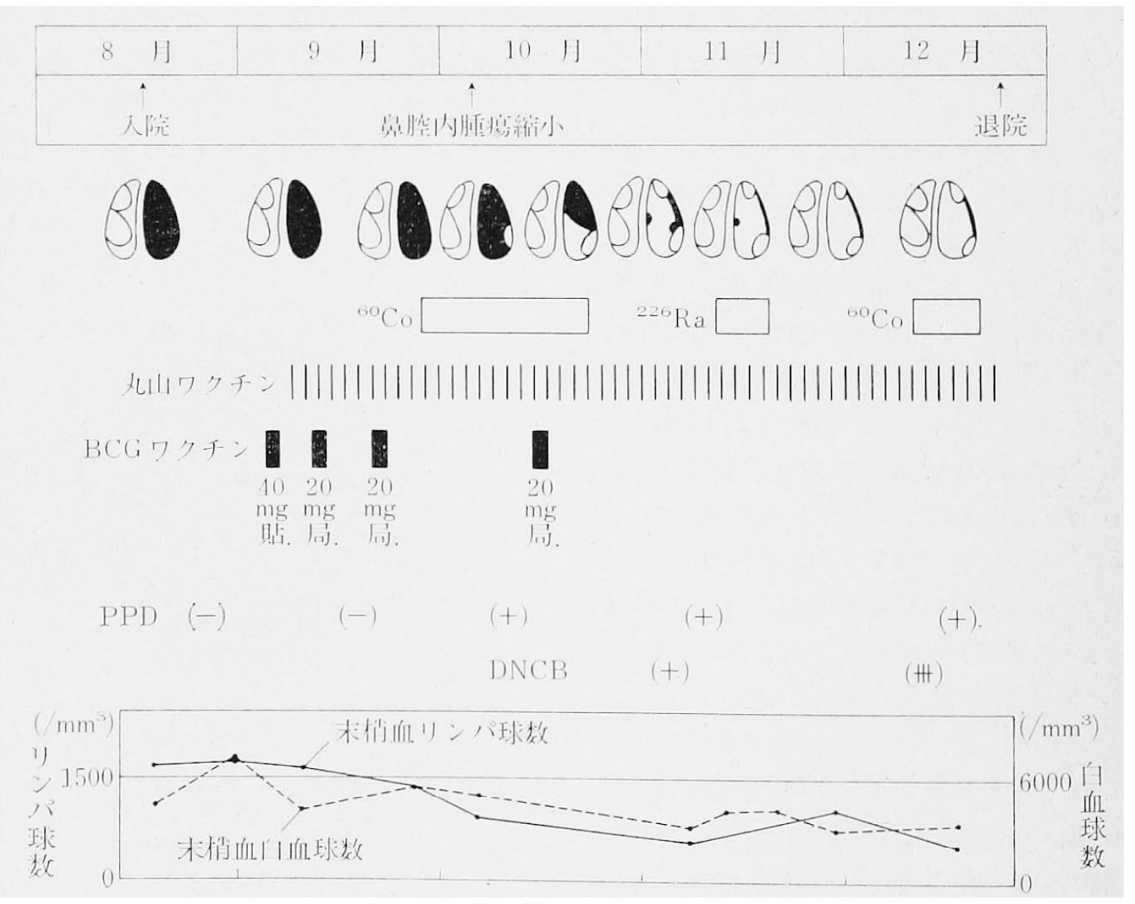

図 6 症 例 6 の 経 過 
腫瘍が次第に增大し， 7 月末より，左側眼窩下部から前 煩部にかけての腫脹を認め, 左眼の視力障害を屯訴吕 た. 8月16日に当科に紹介され，即日入院した.

入院時所見：全身所見では，理学的には特に異常を心

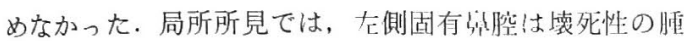
瘍で充満し, 左側䁷翼部の変形腫脹, 左側眼窝下部の䛲脹 を認めた。部X線写真では, 左側上靧洞, 穊骨洞, 固 有鼻腔に腫瘍陰影を認め, 左側上顎洞外侧壁, 下側壁,

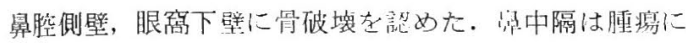
より強く右へ圧排されていた。内科的には，高血王，心 笳障害, 肺気腫を認めた。視力は，左眼は眼前手動，才i 眼は 0.6 , 眼球突出は, 左眼 $26 \mathrm{~mm}$, 有眼 $14 \mathrm{~mm}$ でお った.

経過（図6）：8月17日に，左側罩腔内腫瘍老生検し，

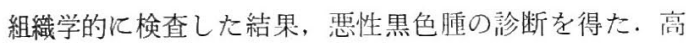

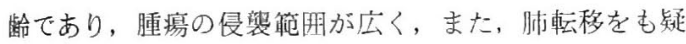
われたので, 手術を施行せずに, ○月。日から BCG ワ クチンを使用し，9月８日から〈山ワクチンを併用し た. BCG ワクチンは、最初, 鼻腔内腫瘍表面に $40 \mathrm{mg}$ 貼布し, 副作用がなかったので，9月13日，9月22日， 10 月 16 日にそれぞれ $20 \mathrm{mg}$ ずつ腫瘍内に局注したが,

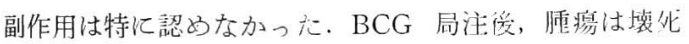
傾向を増したが，腫瘍の増大傾向は続いたのて，9月 27

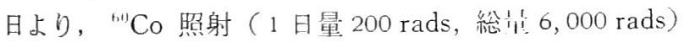
を開始した。10月5日，壊死化した腫瘍塊が脱落した。 その後次第に鼠腔内腫瘍は縮小し, 中鬼道の一部に認好 るのみとなった。図７は，CI-scann 所見で，左側眼窝

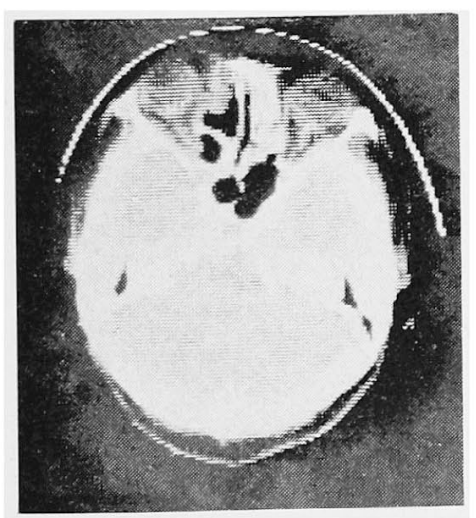

図 7 CT-scann 所見 (orbito-meatal line, 上 $2 \mathrm{~cm}$ ): 左側眼窩内側壁の骨破壊, 左側莡㓐外側前部に 腫瘍の残存を認める。左側篅骨洞，蝶形骨洞は， 右後方へ压排されている。左眼球の突出屯認め る. (昭和 51 年11月25日)
内側壁の骨破壊と, 左側原控側壁に腫瘍の残存を認める. 続いて，11月11日から19日までと，12月2日から9日ま

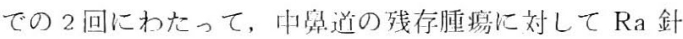
に上る密着照射を施行した。照射量は肺癔表面よりの深 さ $5 \mathrm{~mm}$ で, $20,000 \mathrm{rads}$ とした. 12 月 10 日から 1,000 rads の ${ }^{6 \prime} \mathrm{Co}$ 望隔照射を追加し，12月23日に，寛解退院 した。退院時の視力は, 们眼 0.6 , 左眼 0.4 と改善し, 眼球突出も, 右眼 $16 \mathrm{~mm}$, 左眼 $17 \mathrm{~mm}$ と改善していた。 な扣，PPD 皮内反応は，又院当初は除性であったが， $\mathrm{BCG}$ ワクチン括よひれ山ワクチンの投与開始の 1 力月 後より陽転し, 退院時まで続いている。 DNCB 反応は, 11月4日に(十)，12月11日に(井)であった。杢梢血リン , 球数は、図60ごと々放射線療法閒始後减少傾向を示 した。退院後 6 力月を経た現在, 右側頝部に黒い腫瘤を 1 個認めるが元気であるという報告があったが，来院は していない。

病理組織学的所見: 類円形, 大型の腫瘍細胞が, 疎あ るいは类状に増殖していた。腫瘍細胞の一部は胞体内に

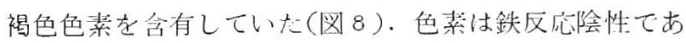
り, Dopa 反応陽性を示した。

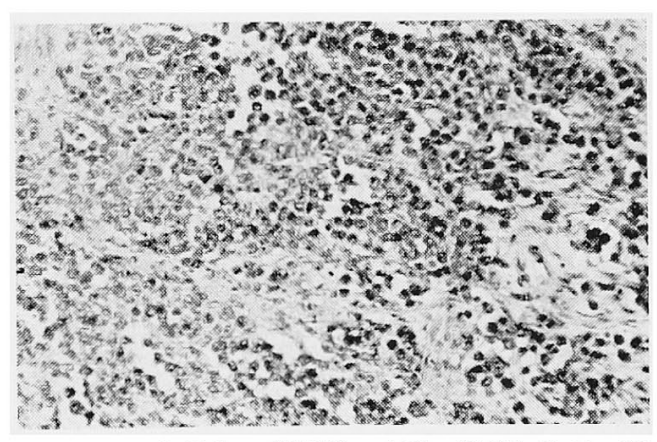

図 8 病理組織像 粘円形, 大型の腄瘳細胞が, 疎, あるいは栄状に増㚲している。腫瘍細胞の一部 は，胞体内褐色色素を含有している。

(H.E. 染色. 100 倍撮影)

\section{III. 考按}

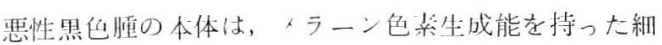

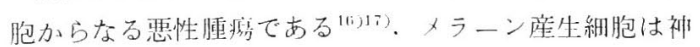
経節 (neural crest) 飞起源すると言和れ, 正常々ラ， サイトおよび色素性母斑の母亥細胞の二種類あり，いず れも悪性黑色腫の発生母細胞になりうる トは,のちに, 神経楖加ら长梢部に移動して主として皮 覤飞定着する。従って, 理諭上は, 皮神以外の身体部分 にも種々な部位に存在することが可能であり, その現缶 
は, 中枢神経采を除けば，姝に粘脱上皮に多く、これら が，皮膚以外から発生する悪性黒色腫の主たる源になる と考光ら机ている ${ }^{18)}$. 粘膜内メラノサイトの分布につい

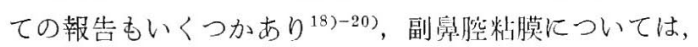
芝田 ${ }^{18)}$ が渡銀法を用いて観察し，21例中 2 例にメラノサ イトの存在を訫めた, われわれも, 鼻・副鼻腔粘膜につ いて, Dopa 反応を用いてメラノサイトを検索し, メラ ノサイトと思われるDopa 陽性細胞を認め, 第78回日耳 舅総会に打いて報告した.耳鼻咽喉科領域の粘膜に発生 する悪性黒色腫の原発部位としては，染・副鼻腔粘膜の

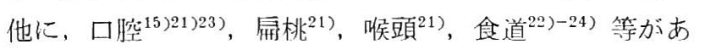
る。それらの中で，本邦に扣いては，口腔粘膜に比較的 多数発生する ${ }^{25) 26)}$.

発生頻度: 悪性黒色腫の発生頻度は, 白人種にくらベ て，日本人などのアジア人種では低いとされている

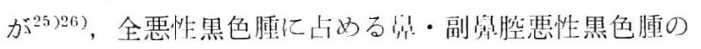
頻度は，日本人の今が白人種よりも数倍の䯩率を示して いる、すなわち, Moore \& Martin'21) によ机ば, 1546 例 中9 例 $(0.5 \%)$, Allen \& Spitz ${ }^{1)}$ によれば, 934例中10 例 $(1.1 \%)$ であるのに対し, 杖邦に少いては, 吉田と久 木田の報告では，403例中 29 例 $(7.2 \%)$, 清寺らの報告 では，501例中37例 $(7.4 \%)$ であったという25)26). 留.

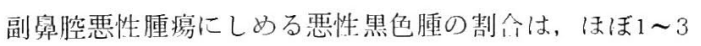
\%台である。すなわら, Holdcraft \& Gallagher" によ れば, 1029 例中37例 $(3.6 \%)$, 酒井ら”゙)は, 908 例中 11 例 $(1.2 \%)$, 島田 $\left.{ }^{15}\right)$ は. 244 例山19例 $(3.6 \%)$, 山際 $5^{53)}$

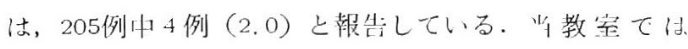
$(1948 \sim 1976) ， 245$ 例中。例 $(2.4 \%)$ でる。. 中村5i

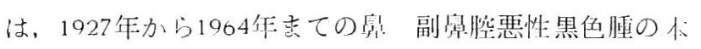
邦報告例を64例集計している。われわれが，1965年から

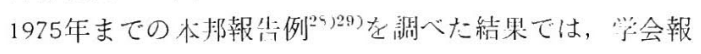
告㧍よび，その追加症例まで含めると，67例で苛っれ。

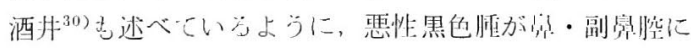

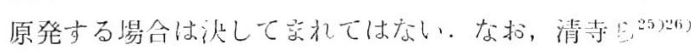

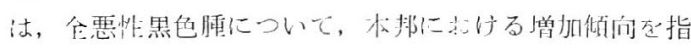
摘している.

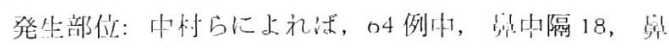

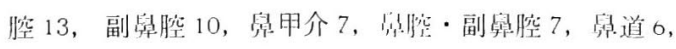
その他 3 となって扣り，Grace ${ }^{31)}$ によれば，63例中，高

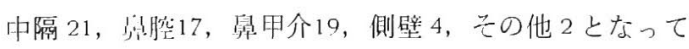
扣り, Holdcraft \& Gallgher によれば, 39 例中, 鼠中

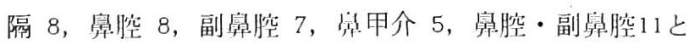
なっている.われわれの集計では, 舅甲介11, 買中隔8,

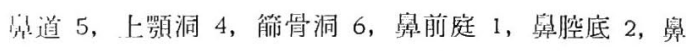
腔・副晞腔 2, 鼻腔 28 であった鼻・副鼻腔悪性黒色腫 は，舅腔原発例が副鼻腔原発例よりも数倍多いが，その 理由として，鼻腔粘膜と副徼腔粘膜とのメラノサイトの 分布の䢖い, 外界からの物理的, 化学的刺激の違い等が 考えられるが，これらと黒色腫発生との確实な因果関係 は不明である。

年秢・性別: 性别飞大差はないという報告が多(919) 21)31)が，男性飞多いという報告6)11332) と，女性飞多いと

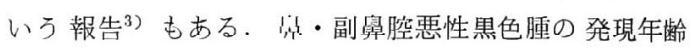

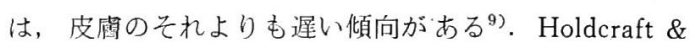
Gallagher によれば，50 代から70 代に多く，最少年齢 は17歳, 最高年制は84歳であったという。本邦において は, 中村らは, 50 代から60代に最む多く, 最少年齢は19 㳚，最高年踰は69歳であったという。われわれの集計で は, 70 代 9 例, 80 代 2 例と高年粭層に増加傾向を認めて いる(圭1).

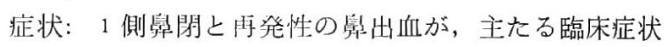

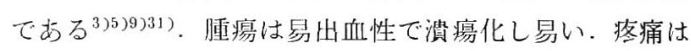
少ない, 外察の変形, 腫脹, 鼻腔内腫瘤等もしばしば訴 えられる。

診断：舅腔内に現われる腫湯の形はさまざまで，暗裮

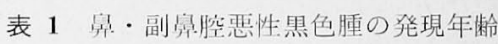
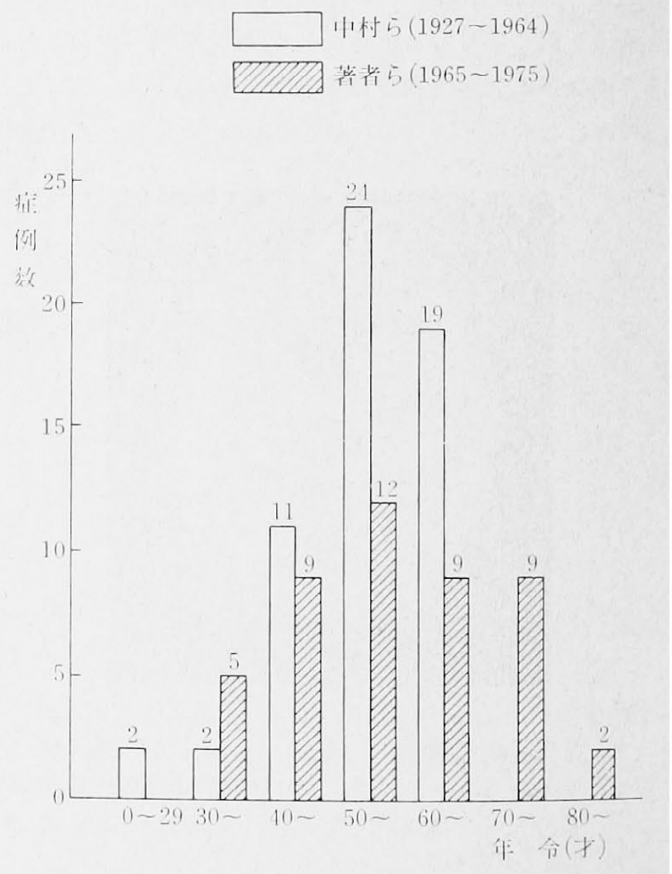
色鼻茸状の所見を呈する場合が多いが，赤褐色ないし黒 䋵色鼻茸状，力リフラワー状，脟には，腫演細胞にメ ラニン顆粒がみられず，淡縕色を带びた amelanotic melanomaとして見られるなど多様な所見を示す. Allen \& Spitzによれば, 悪性黑色厘のメラ二ン色秦汇よる着 色は，皮咸のそれより志，粘膜のそれに少なく，粘膜の 悪性黒色腫の約半数は，着色を大くという，隀瘍は易出 血性で比較的軟かいことが多い，腫瘍が率咠状を呈する ため，鼻苹切除術の既往のある例が多く，Holdcraft \& Gallagher は39例中 5 例 (13\%), Grace は48例中18例 (37.5\%) 飞鼻茸切除術の既往を認めている。われわれ心 例でも半数（３例）が，鼻茸または出血性鼻草の㟝断に て鼻茸切除術を受けている。罳茸切除術や外傷が，悪性 黑色腫発生の誘因となったという報告 ${ }^{3}$ (1) もあるが，わ
れわれの症例では，切除された舅茸がすでに照色盾の一 部であったと推祭している、いずれにしても，知床像の

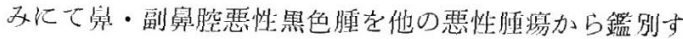
ることは非常に難しく，確定彰断には，病理組織学的㭘

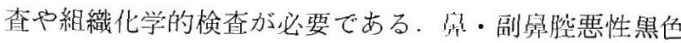

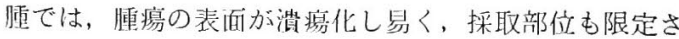
れるために，生検の際に表面の壤死組織を採取すること があり，手術時まで參断がつかないこともしばしばあ る。

病理組織学的所見: 福代・広根 ${ }^{16)}$ は, 悪性黑色腫の組 織像は多彩であり，真皮内に侵入増殖した腫揚細胞は， 症例によって，また同じ腫瘳でも部位によって，形・大 きさ・配列などに著しい差異を示すと述へ，類円形細胞 からなる胞巣状權造が顕著な場仝，紡錘形細胞からなる

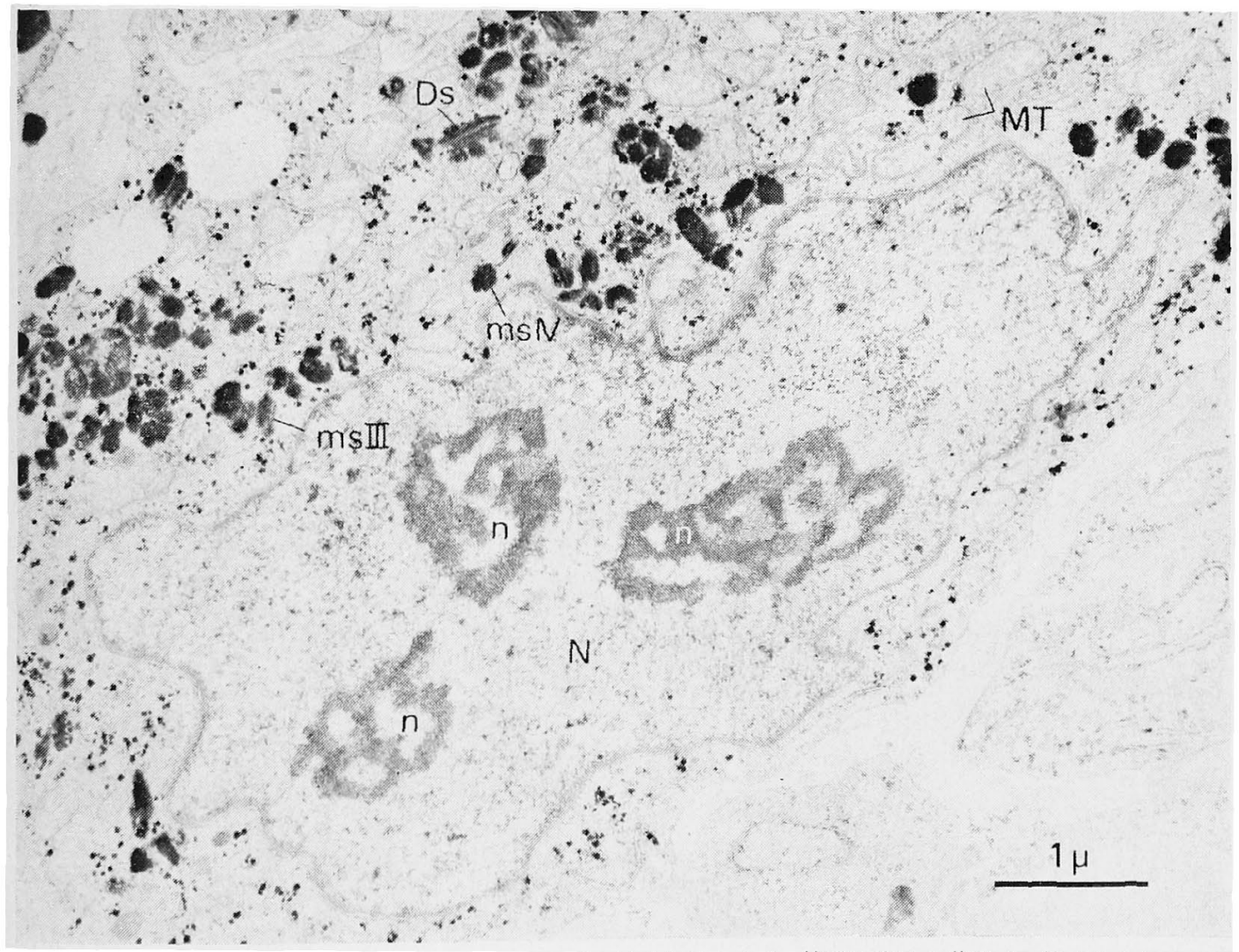

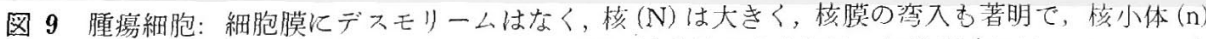
も大きく，網状博造を示し，断面像では３個の㤥小体がみられる。細胞質内には。メラーン生 成過程である stage III のィラノソーム (ms III), メラニンが生成され成熟したなラノソーム

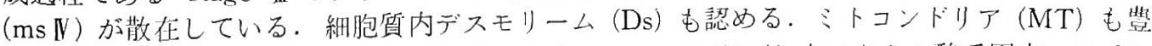
富に見られ，一部は膨化し変形している（グルタルアルデヒド・オミウム酸重固定，エポン

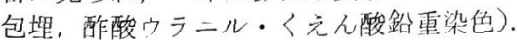


束状欂造が頻著な場合，種々の大きさと形の細泡が粗ま たは密に雑然と巨細胞をまじえて存在する場合などいる いろであると述べている.三島ら゙゙は, pagetoid 型悪性 黒色腫について記惟し, 組織学的には, 買型色素細胞の 特徽的な pagetoid invasion が, 表皮内の上方と, 側方 向人見ら机るとし, 粘膜にも発生するとした. Holdcraft \& Gallagher 汭, 悪性黒色媑の組織像は種々の夕イブの 腫瘍と似ているので，证確な診断を下すのが退れると し, 特に, 腫沮が色素を人いている場合に顕著であると 意っている. そして, AFIP の症例中, $51 \%$ は, 生検後 数日で唯定診断を下されたが，残りの $49 \%$ は，1 力月ま たはと机以上かかったと述べている。望った讋断名とし ては, 未分化癌, 低分化需平上皮癌, angiomyosarcoma, 細絓肉腫，移行上皮癌，embryonal rhabdomyosarcoma， および悪性 schwanoma 等である.これらの腫瘍では, 出血による褐色の色素（へモジデリン）の存倠が，診断
を複雑にしている.われわれの 6 症例中 5 例の組織像 は, 類円形, 胞巣状棈造が著明で，1例は, 紬鍾形細胞 からなる束状神造が著明であった． Pagetoid 型悪性黒 色腫の存在は，被覆粘膜上皮がすでに壊死飞宿っていた り，欠損している場合が多く，判然としなかった.

組織化学的検査: メラノサイトの構造を特異的に染出 すると同時にメラニン形成能を観察する組織化学的方法 として, Dopa 反応, Tyrosine 反応, Premelanin 反 応, Dopa-premelanin 反応がある ${ }^{36)}$. メラニン色素を, へモジデリン等の血色素由来の色素と鑑別するには， へ ルリン畒反応等の鉄反応を施行し，3価鉄イオン㓌性を 証明すればよい。

分類: Clark ら ${ }^{35)}$ は, 主として臨床像と組織像とか ら，㿪阙の悪性黒色腫を，1). Superficial spreading melanoma (SSM), 2). Nodular melanoma (NM), 3). Lentigo maligna melanoma (LMM) の3 型飞分け

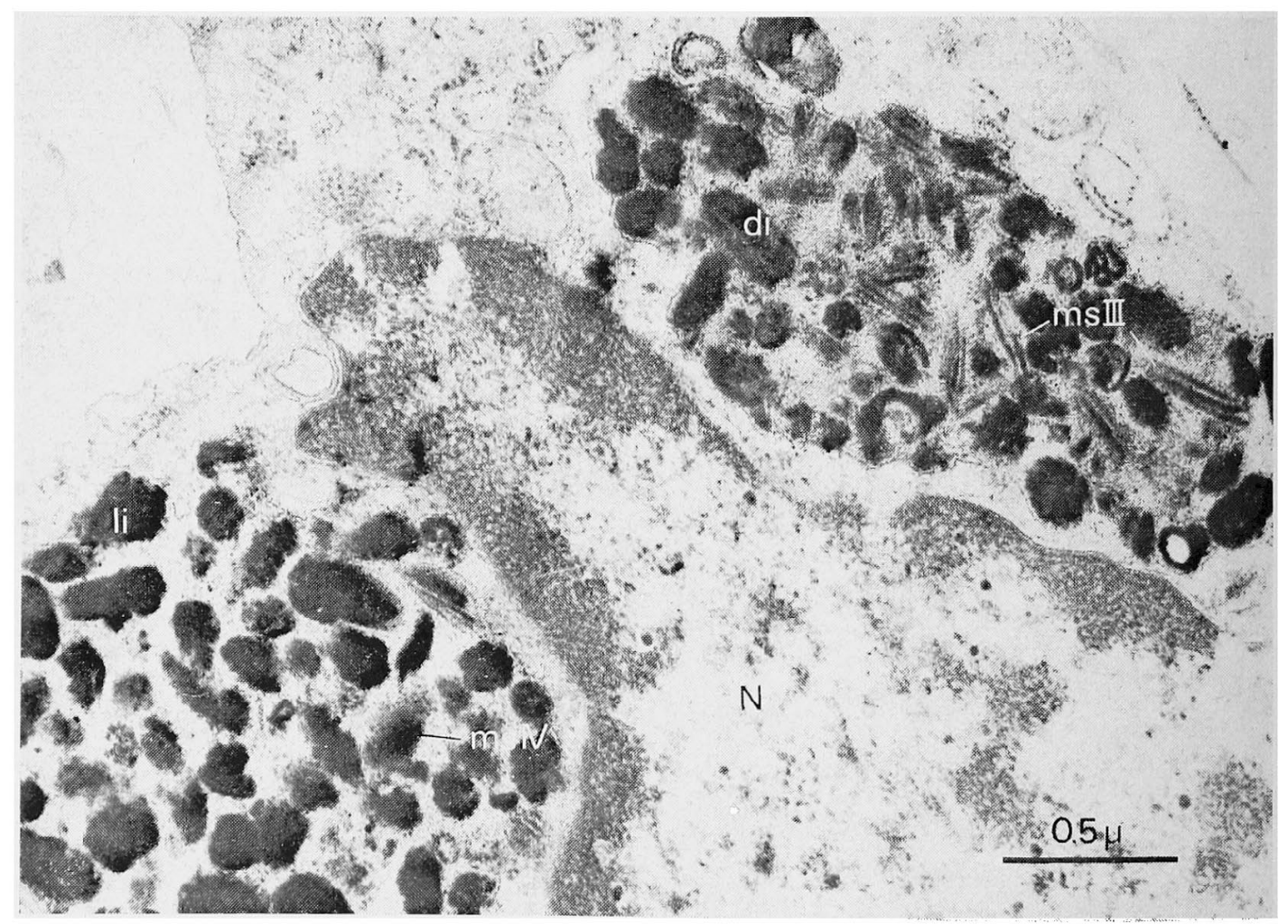

図 10 Melanophage: 二種類のメラーン封入休が見られる. 右上は, 紡鍾形, 線維状構造を示す, stage III のメラノソーん（ms III）を主とした暗いメラニン封入体 (di)で, 左下は, 成熟した stage IV のメラノソーム (ms IV) を主とした明るいメラニン封入体(li) である.（グルタルア ルデヒドオスミウム酸重固定, 酢酸ウラニル・くえん酸鉛重染色). 


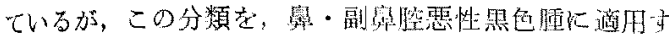
るКは，発生部位の特殊性のために現段階ではデータが 不足している. 石原ら ${ }^{233}$ は，43例の覀性黒色腫のうち， 級胞型拈よび生存年数を判定し得た30例について，組緎 学的飞，1）紡鍾緗胞型，2）大型上皮様細胞型，3）小

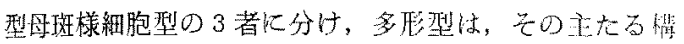
成絸胞群をもって3者のいず机江含めて，平均生存年 数妾検討し，新䤡細胞型 14 例の平均生存年数结 39.0 力 月, 大型上皮様細咆型14例では23.6力月，小型诗斑㴍細

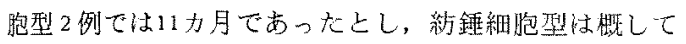

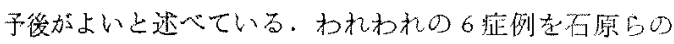

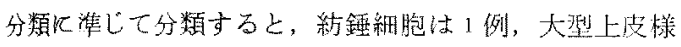
細胞型は5例で，小型母斑様細胞型を示した例はなかっ

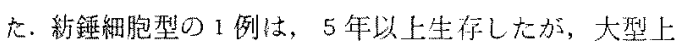
波様細胞型 5 例中, 1 年以内死亡 3 例, 2 年以内死亡 1 例 て，現在，10力月以上生存例が 1 例あるのみでる。 新 錘細胞型の予後がよいという石原らの絬果は，われわ机 ○例飞も古てはまる。福代・広根 $\left.{ }^{16}\right)$ は, 微細瑇造の上加

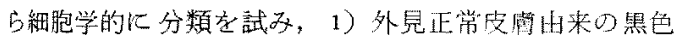
腫，2）悪性黑子由来の黑色腫，3）目斑細胞由来の黑色

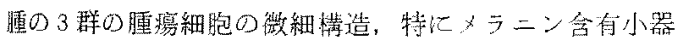

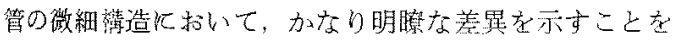

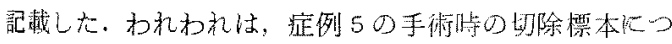

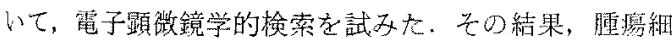
胞は。図9に示すように，細胞膜にデスモりームはな く，核は大きく，核膜の弯入も著明で，核小体香大き

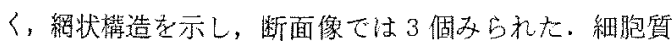
内には、メラニン生成過程である stage IIIのメラノソー

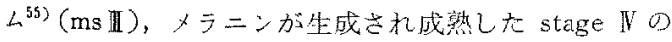
イライソーム( $\mathrm{ms} \mathrm{W}$ )が散在している。細胞内デスモり 一ん(Ds)も認わる. Melanophage に批いては, 図10に 示すように，二種類のメラーン封入体を認好。ひとつ は,メラノソーム正を主とした発達段階のメラニン封入 体て，暗く見天る。他のひとつは，成熟したなラノッ一 ムWが主体の明るいタラーン封人体である。この推例の メラニン含有小器官の微細構造は, 福代・卮根の分頑て

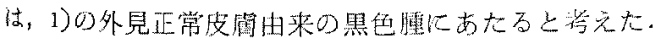

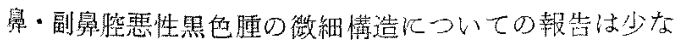
(933757), 今後の砄究が期待される。

治㙩: 悪性黑色腫の治療法として恃，表2 亿示すよう

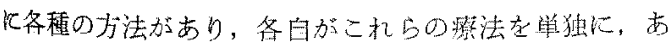
るいは，各種組み合わせて，治療成績の向上者図ってい

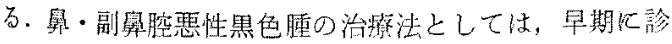

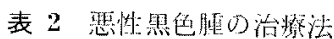

1. 手術療法
i. 広沉な切除

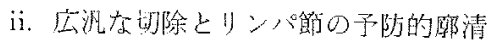
iii. Cryosurgery

2. 敃射線湶法

i. Ra 照射, ${ }^{6 n} \mathrm{Co}$ 照射, 顿L線 (Dermopan) 照 射, 雷于線照射

ii．クロールブロマジン往よる放射線增感療法

3. 化学潦法

DTIC, hydroxyurea, vincristine, methotrexate, mitomycin $\mathrm{C}$, bleomycin

4. 免㾂痖法

BCG, BCG-CWS, OK-432, S.S.M.

5. 食慨燎法。

tyrosine L phenylalanine 上在除いた念䬣の 控取

断出来た場合には，健常部分を含えだ店沉な切除と，所属

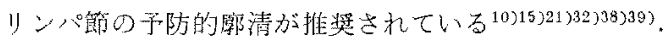

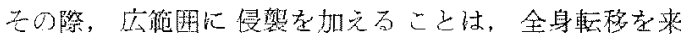
たしやすくするということをも念頍に括いて，手術て治 傯させ得る状態加否加，慎重化判断する必要がある。 Conley $b^{32}$ は，臨床的飞転整のない小さい墨色臛は切 除単独がよいと述べてい西。美た，Cryosurgery の有效

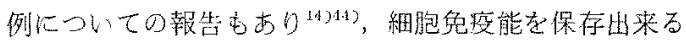
之いう点から本，今捘に期待の持たれる燎法である。悪 性黑色堙の細胞は，族射線江対与る抵抗力が强いため，

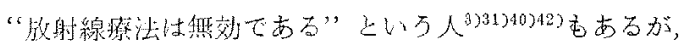

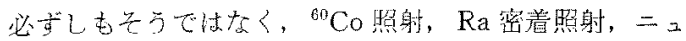

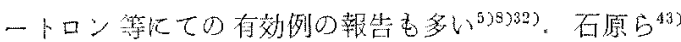
は, 一ュートロン以外の放射線では単独治療は行なら心゙

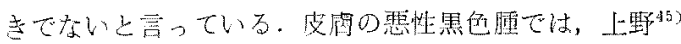

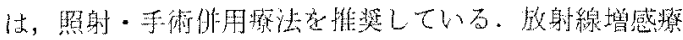
法として，三鼠(10)のクロルプロマジン投与法があり，

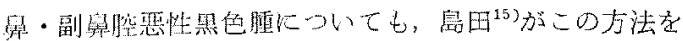

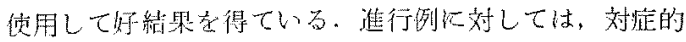

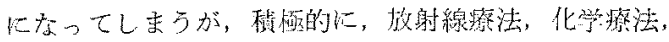

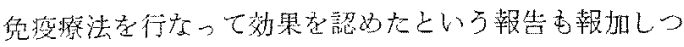
つある.化学療法郕ては，Wright ${ }^{(1)}$ は, methotrexate の有效であった1例孝報告して和り，Gutterman ら は, 化学寮法剂 DTIC (dimethyl triazeno imidazole 


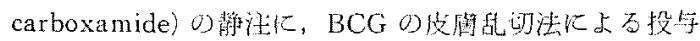

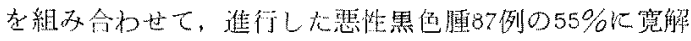

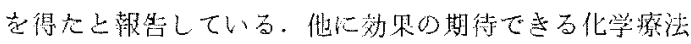

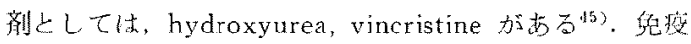

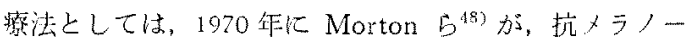
マ抗体の存在に着目して，8人の瑟性照色睡毁者にBCG

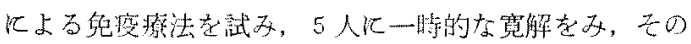

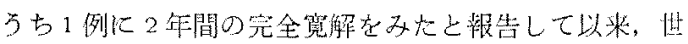

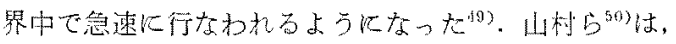
副作过の少空い BCG-CWS ワクチンを四発し，悪性

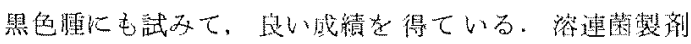
(OK-432) も，覀性黑色膄に有効であったとい万報告が

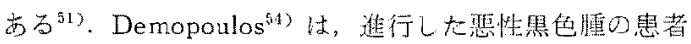

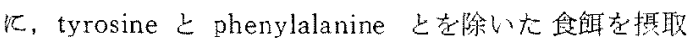
させることによって，5例中 3 例に睡痛の維小在みたと している.

以上の治療法の文献的考然とわ和われの症例の治撩経

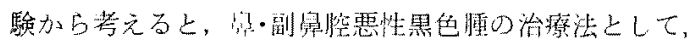
早期には，健常部分在含んだ公汎な切除儿，所属りンパ

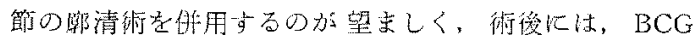

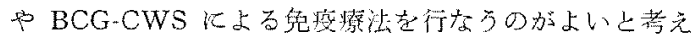
る。進行例和上ぴ再発例で，切除不能の煬含には，化学

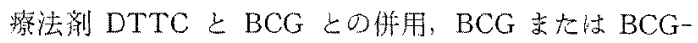
CWS の間注とRa などの小線源による大䝿照的, ${ }^{60} \mathrm{Co}$

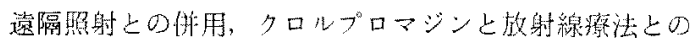

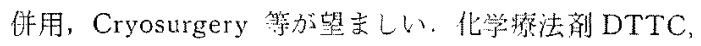
hydroxyureaは，本邦では手に入りにくいので，われわ

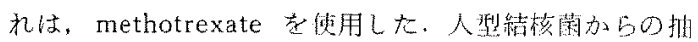
出物嘶である丸山ワクチン (S.S.M.) も，作用古るのが

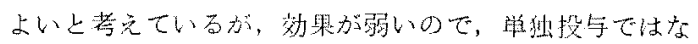

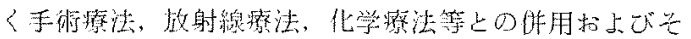

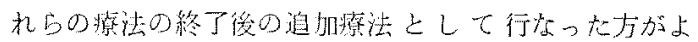
i.

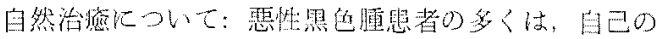

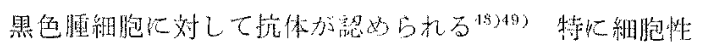

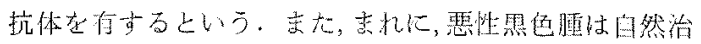

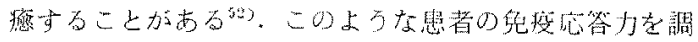

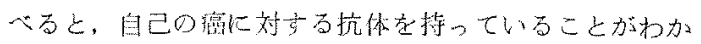

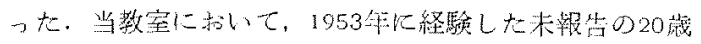

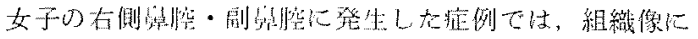

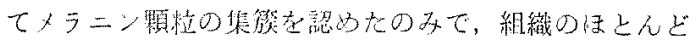

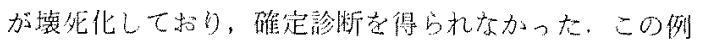

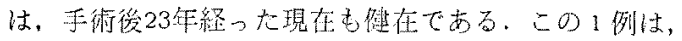

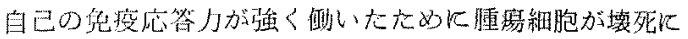
陷な大可能性加強い上考えている。

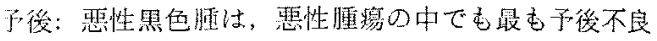

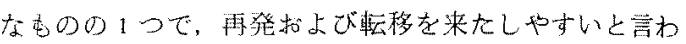

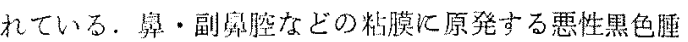
の丁後は，皮閔のてれよりもさらに不良である. Allen

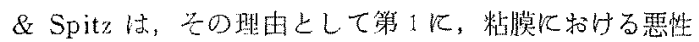

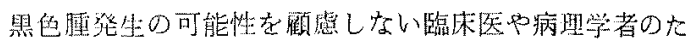

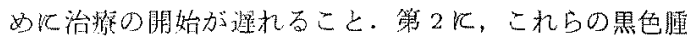

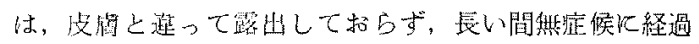

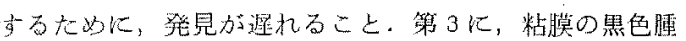

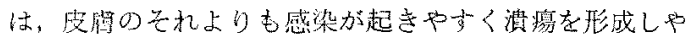
すいこと、第 4 に粘膜の照色腫の大きさ方，皮圆のそれ

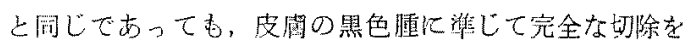
することは，その発生部位の特殊性加口困難てあるこ

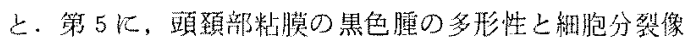

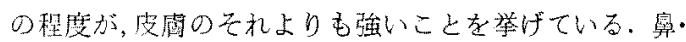

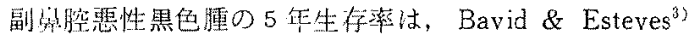
飞よれ栝117 例中 7例 $6 \%$ ), Holdcraft \& Gallagher によ机ば226例中24例（11\%）飞すぎ圾い，早期新断と 適切な治療が手後を良くするこ上は刎諭であるが，それ

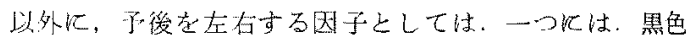
腫の種類であり，皮周の悪性黑色腫ては，黑色癌䐀駆埞

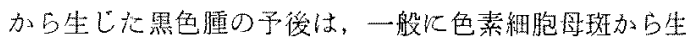

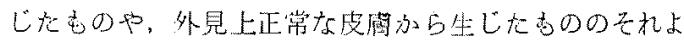

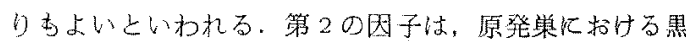
色䑾の侵入の樑さで，侵入の樑さが澡いはど予後がわる

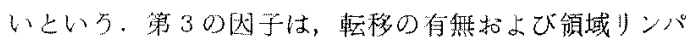
節の观䈯であり，転移のなかった群，領域りンパ節処置 群の方が子後はよ(1735).

\section{N. 結語}

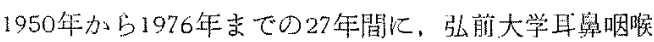

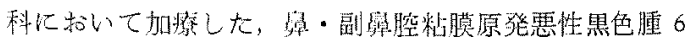

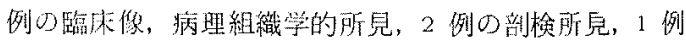

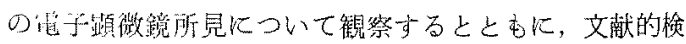

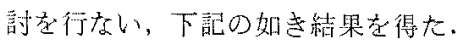

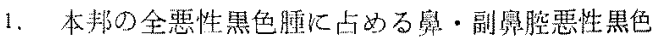

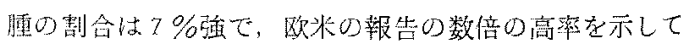

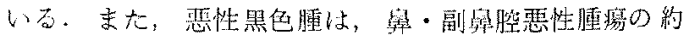
$1 \sim 3 \%$ 上める。

2.1965年加61975年までの本郝報告例は67例苛り，

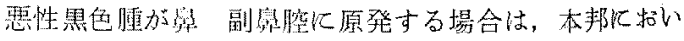
てはまれではない。 


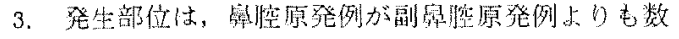
谙多的。

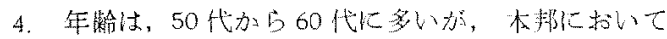

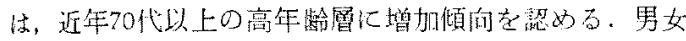
差ば漂上んどない。

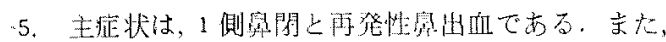

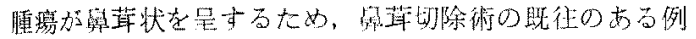
怔多い。

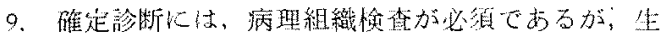

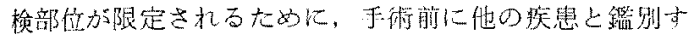
るのが嚾かしい場合がある。

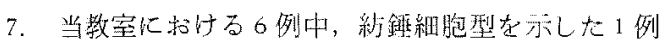
は5 年以上生存し，予後良好であったが，大型上皮様組 胞型 5 例中, 現在10力月生存例が1例方るのみで, 他の 4 例はすべて，1年6力月以内に死亡し，学後不良であ , た.

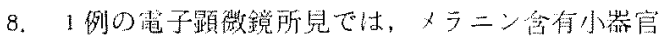

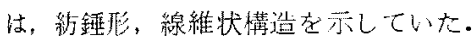

9. 2 例の剖检所見ては，1例は，照転移招上び，影

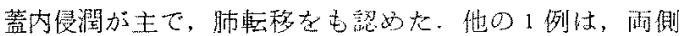

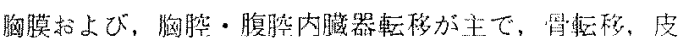
成転移を本㑇的大。

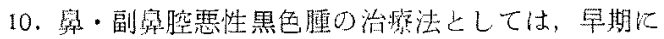

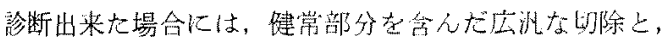

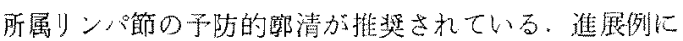
对しては, Cryosurgery, 放射楾酱法, 化学䝤法, 免疼

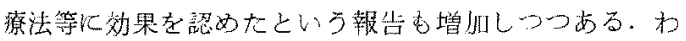
れわれの1例机执ても，BCG上 ${ }^{60} \mathrm{Co}$ 遠隔照射の价用

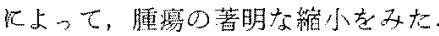

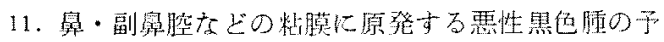
後は，皮嫾のる扎上り毛さらに不良である。

\section{文献}

1) Allen, A.C. \& Spitz, S.: Malignant melanoma; A clinicopathological analysis of the criteria for diagnosis and prognosis. Cancer, 6; 1-45, 1953.

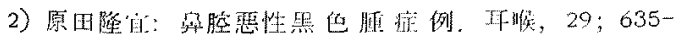
$638,1957$.

3) Ravid, J.M. @ Esteves, J.B.: Malignant melanoma of the nose and paranasal sinuses and juvenile melanoma of the nose. Arch. Otolaryng., $72 ; 431-444,1960$.

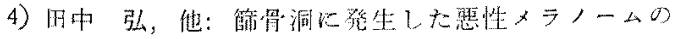

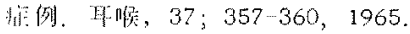

5) Crone, R.P.: Malignant amelanotic melanomas of the nasal septum and maxillary sinus. Laryngoscope, 76; 1826-1833, 1966.

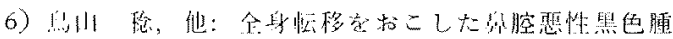
OI例. A7F, 69; 2055-2059, 1966.

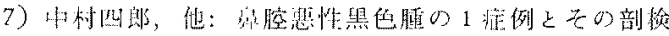
所贶。四喉, 39; 45-54, 1967.

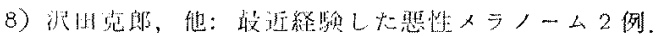
당. 40; 121-125, 1968.

9) Holdcraft, J. Gallagher, J.C.: Malignant melanomas of the nasal and paranasal sinus mucosa. Ann. Otol., 78; 5-20, 1969.

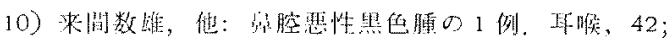
945-949, 1970.

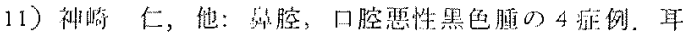
积, $43 ; 447-454,1971$.

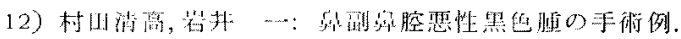
耳陪林，65；1359-1364, 1972.

13) Wright, J.L.W. \& Heenan, P.J.: Prolonged survival in malignant melanoma of the nose. J. Laryng., 88; 77-83, 1974.

14) Barton, R.T.: Mucosal melanomas of the head and neck. Laryngoscope, 85; 93-99, 1975.

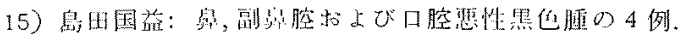
平喉, 48; 927-933, 1976.

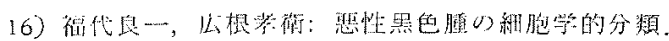

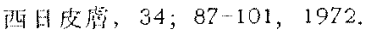

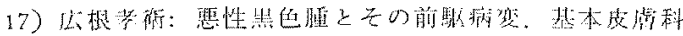

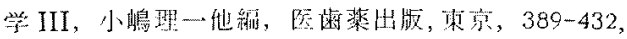
1976.

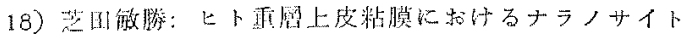

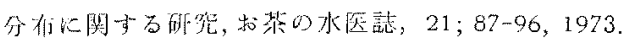

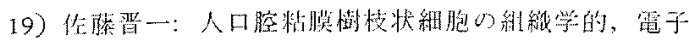

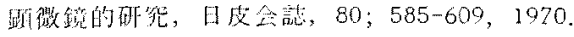

20) Gordman, J.L. et al.: The presence of melanocytes in the human larynx. Laryngoscope, 82; $824-835,1972$.

21) Moore, E.S. E Martin, H.: Melanoma of the upper respiratory tract and oral cavity. Cancer, $8 ; 1167-1176,1955$.

22) Frable, W.J. et al.: Primary malignant melanoma of the esophagus; A electron microscopic 
study. A.J.C.P., 58; 659-667, 1972.

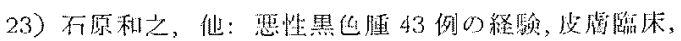
$14 ; 405-412,1972$.

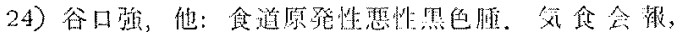
$26 ; 313-320,1975$.

25) Seiji, M. B Ohsumi, T.: Statistical study on malignant melanoma in Japan (1961-1970), Tohoku J. exp. Med., 107; 115-125, 1972.

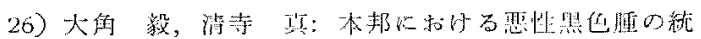

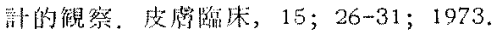

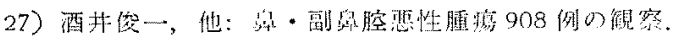
耳度, 21; 859-884, 1975.

28）幍学中车維誌, 202-341；1965-1976.3.

29) 日聑, 68-78, 1965-1975.

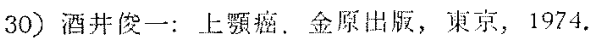

31) Grace, C.C.: Malignant melanoma of the nasal mucosa. Arch. Otolaryng., 46, 195-210, 1947.

32) Conley, J.J. \& Pack, G.T.: Melanoma of the head and neck. Surg., Gynec. and Obst., 116; $15-28,1963$.

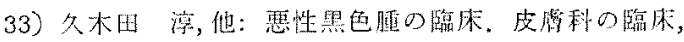
3; 519-528, 1961.

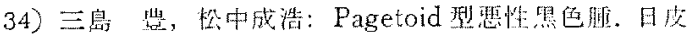
食誌. $81 ; 925,1971$.

35) Clark, W.H. et al.: The histiogenesis and biologic behavior of primary human malignant melanomas of the skin. Cancer Res., 29; 705-726, 1969.

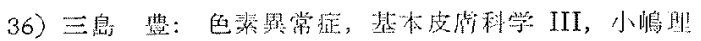

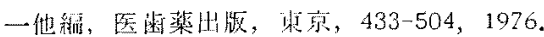

37) 竹中文一毁, 他: Human malignant melanoma o

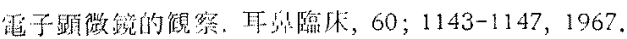

38) Schoolman, J.G. Anderson, H.W,: Malignant melanoma of the nose and sinuses. Ann. Otol, $59 ; 124-140,1950$.

39) Goldsmith, H.S. et al.: Prognostic significance of lymphnode dissection in the treatment of malignant melanoma. Cancer, 26;606-609, 1970.

40) Alexander, F.W.: Malignant melanoma of the nasal septum. Laryngoscope, 64; 123-129, 1954.

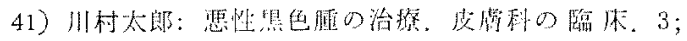
529-538, 1961.

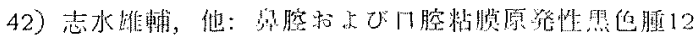

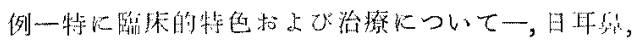

$25 ; 1120-1121,1972$.

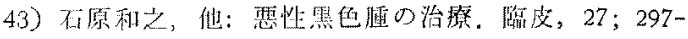
$304,1973$.

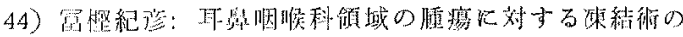

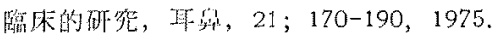

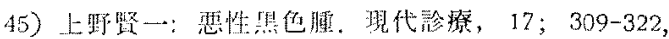
1975.

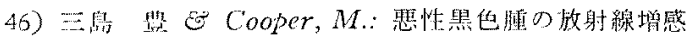

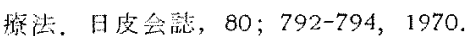

47) Gutterman, J.U. et al.: Chemoimmunotherapy of disseminated malignant melanoma with dimethyl triazeno imidazole carboxamide and bacillus calmette-Guérin. New Engl. J. Med., 291; 592$597,1974$.

48) Morton, D.L. et al.: Immunological factors with infuence response to immunotherapy in melanoma. Surgery; 158-164, 1970.

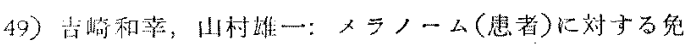

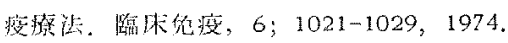

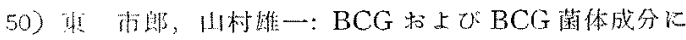

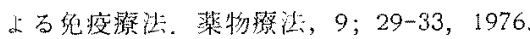

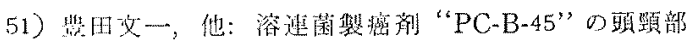

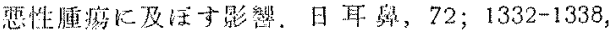
1969.

52) Sumner, W.C.\& Foraker, A.G.: Spontaneous regression of human melanoma. Clinical and experimental studies. Cancer, 13; 79-81, 1960.

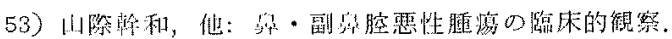

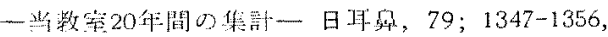
1976 .

54) Demopoulos, H.B. Effects of reducing the phenylalanine-tyrosine intake of patients with advanced malignant melanoma. Cancer, 19, 657$664,1966$.

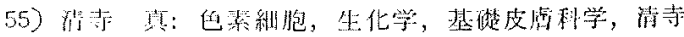

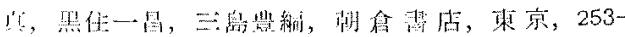
264,1973

56) Richter, G.W. Ef Epstein, M.A.: International review of experimental pathology. vol. 2 Droch* mans, P.; Melanin granules; Their fine structure, formation, and degeneration in normal and pathological tissues. Academic press, New York and London, 356-423, 1973. 


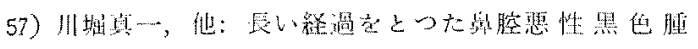

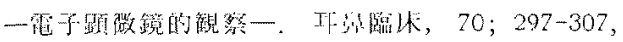
1977.

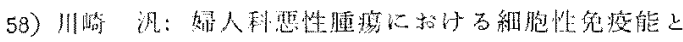

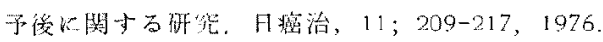

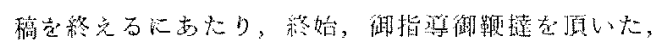

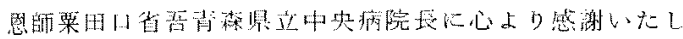

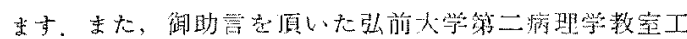

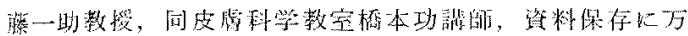

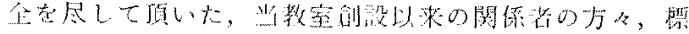

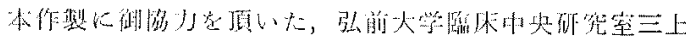

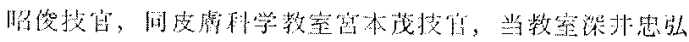

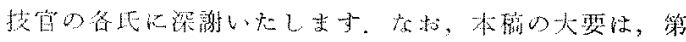

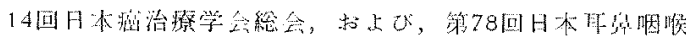

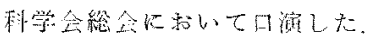

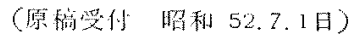

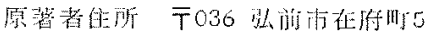

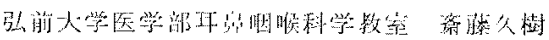

